ENTREPRENEURSHIP AND SUSTAINABILITY ISSUES

ISSN 2345-0282 (online) http://jssidoi.org/jesi/

2021 Volume 9 Number 2 (December)

http://doi.org/10.9770/jesi.2021.9.2(32)
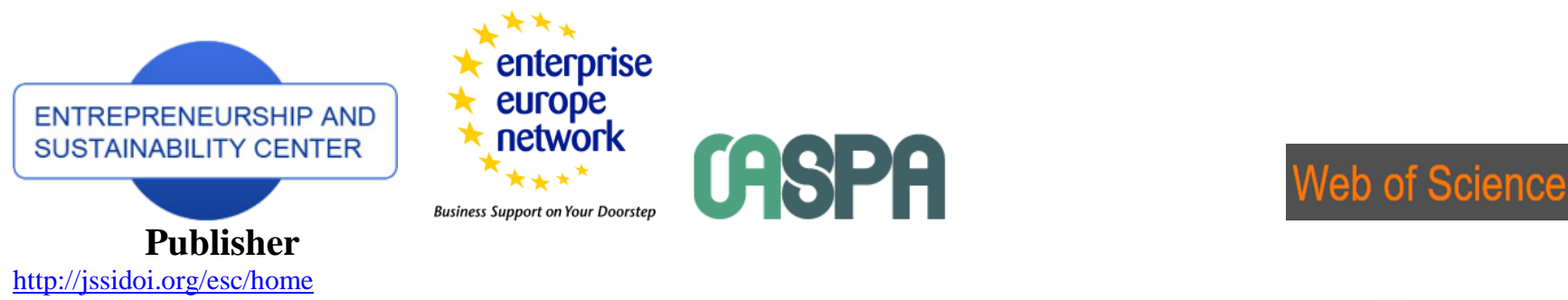

http://jssidoi.org/esc/home PA

1 Clarivate

Analytics

\title{
THE ROLE OF TALENT IN THE ECONOMIC DEVELOPMENT OF COUNTRIES IN THE MODERN WORLD
}

\section{Liene Leikuma-Rimicane ${ }^{1}$, Vera Komarova ${ }^{2}$, Jelena Lonska ${ }^{3}$, Natalya Selivanova-Fyodorova ${ }^{4}$, Inta Ostrovska ${ }^{5}$}

\author{
1,2,5 Institute of Humanities and Social Sciences, Daugavpils University, Parades Str. 1, Daugavpils, LV-5401, Latvia \\ ${ }^{3}$ Business and Society Process Research Center, Rezekne Academy of Technologies, Atbrivosanas alley 115, Rezekne, LV- \\ 4601, Latvia \\ ${ }^{4}$ RISEBA University of Applied Sciences, Meza Str. 3, Riga, LV-1048, Latvia
}

\author{
E-mails:. ${ }^{1}$ liene.rimicane@du.lv; ${ }^{2}$ veraboronenko@inbox.lv; ${ }^{3}$ jelena.lonska@rta.lv; ${ }^{4}$ nsel15@inbox.lv; \\ ${ }^{5}$ inta.ostrovska@du.lv
}

Received 14 September 2021; accepted 15 November 2021; published 30 Decemeber 2021

\begin{abstract}
The purpose of this article is to empirically test the role of talent in the economic development of countries in the modern world. As the main research method, the authors use regression analysis, which involved variables characterizing the talent competitiveness of countries, as well as indicators of countries' economic development. The authors use two indicators to empirically measure the economic development of countries in the modern world. The first is a static indicator, GDP per capita, which measures the economic performance of the world's countries. Second, the dynamic indicator of the average change in GDP per capita over the previous 10 years measures the economic growth of the world's countries. Correlation analysis is used as an additional research method. The results showed that talent is a stable and practically the main determinant of such an important element of the economic development of countries as their achieved state of economic development. At the same time, the talent competitiveness of countries is not the engine of their short-term economic growth. For economic growth, it is enough to attract talent from outside, but for the economic development of the modern world's countries to be sustainable, it is also necessary to be able to grow talents and create conditions for their efficient work within the country. All of these elements are included in the Global Talent Competitiveness Index. Based on empirical results, the authors propose to replace the Global Competitiveness Index (GCI) with the Global Talent Competitiveness Index (GTCI) in research practice. Then the talent will also be included in the conceptual understanding of countries' competitiveness in the modern world.
\end{abstract}

Keywords: talent; economic development; economic performance; economic growth; talent competitiveness

Reference to this paper should be made as follows: Leikuma-Rimicane, L., Komarova, V., Lonska, J., Selivanova-Fyodorova, N., Ostrovska, I. 2021. The role of talent in the economic development of countries in the modern world. Entrepreneurship and Sustainability Issues, 9(2), 488-507. http://doi.org/10.9770/jesi.2021.9.2(32)

JEL Classifications: F63, F66, J24

Additional disciplines: sociology 


\section{ENTREPRENEURSHIP AND SUSTAINABILITY ISSUES}

ISSN 2345-0282 (online) http://jssidoi.org/jesi/

2021 Volume 9 Number 2 (December)

http://doi.org/10.9770/jesi.2021.9.2(32)

\section{Introduction}

At the end of the 20th century, a human-centered approach to assessing the economic development of countries was formed in the world economy (Cubas et al., 2016; Zhang \& Zhao, 2018; Ding et al., 2020; Yang \& Pan, 2020; Tsvyk \& Tsvyk, 2020; Raudeliuniene et al., 2020; Shevyakova et al., 2021). This approach was based on the importance of people as the main driving force behind the country's economic development. Many researchers believe that one of the main reasons for the economic differentiation of the world's countries today is the unequal distribution of people in geographic space (Gibbons et al., 2010; Gibbons \& Vignoles, 2011; Kline \& Moretti 2014). In terms of creative class theory, this is an unequal distribution of talents (Florida, 2002a, 2002b, 2003; Cowling, 2009; Gu et al., 2020).

"Sustainable Development Strategy of Latvia until 2030" emphasized: "The concept of capital is used here in a broad sense and includes elements that are difficult to express directly in money. Our main capital is people, their abilities, knowledge and talent" (MEPRD, 2020). Furthermore, the Latvian "Human Development Report 2006/2007. Human Capital" noted that in industrial societies competitiveness and prosperity are determined by means of production and other material values. In turn, in a knowledge society, the main source of well-being and development is a set of human abilities and skills (Zobena, 2007).

The aim of this article is to test empirically the above statements in order to prove the role of talent in the economic development of countries in the modern world. For the theoretical substantiation of the study, the authors rely on the creative class theory of R. Florida (Florida, 2002a, 2002b, 2003). According to this theory, the human talent now increasingly determines the economic development of a territory. The role of talent trumps the importance of natural resources and physical capital. The source of empirical information for this study is data for 2016-2018 of the Global Competitiveness Report (GCR) of the World Economic Forum (World Economic Forum 2016, 2017, 2018, 2019), as well as data for 2016-2019 of the report on the Global Talent Competitiveness Index's (GTCI) (INSEAD, 2017, 2018, 2019, 2020).

The authors use the Global Talent Competitiveness Index as a tool for the empirical measurement of a country's talent competitiveness in terms of its ability to enable, attract, grow and retain talented people on a country's territory. The authors use two indicators to empirically measure the economic development of countries in the modern world. The first is a static indicator, GDP per capita, which measures the economic performance of the world's countries (Porter, 2003; Stankevics et al., 2014; NZIER, 2014; Boronenko et al., 2014; KondratiukNierodzinska, 2016). Second, the dynamic indicator of the average change in GDP per capita over the previous 10 years measures the economic growth of the world's countries (Krysovatyy et al., 2020; Cizo et al., 2020). The authors used linear regression analysis as the main method of the empirical study of the influence (Cizo et al., 2020) of the countries' talent competitiveness on their economic development in the modern world.

The main limitation of this study is that the time period for empirical investigation is only a few recent years (not including the years of the Covid-19 pandemic). This allows the authors to assess the role of talent in the economic development of countries in the modern world in the pre-pandemic period. Although, the authors believe that the pandemic did not weaken, but, on the contrary, strengthened the role of talent in the economic development of countries. 


\section{ENTREPRENEURSHIP AND SUSTAINABILITY ISSUES}

ISSN 2345-0282 (online) http://jssidoi.org/jesi/

2021 Volume 9 Number 2 (December)

http://doi.org/10.9770/jesi.2021.9.2(32)

\section{Theoretical background}

There are many works in the scientific literature devoted to the so-called "geography of talent" (Andersson, 1985; Florida, 2002a; Kerimoglu \& Karahasan, 2012; Burzynski et al., 2018; Jiang et al., 2020; Gu et al., 2021). J. Rauch defined talent as a local public good (Rauch, 1993; Tian \& Liu, 2018). He believes that workers with equal productivity will earn more in countries and regions with a higher talent competitiveness score (INSEAD, $2017,2018,2019,2020)$ than in countries and regions with a lower one. This is due to the external effects of the talent competitiveness of countries (Rauch, 1993).

Talented people concentrated in a specific geographic area create the basis for the formation of so-called creative industries or creative clusters. The role of creative industries and creative clusters for territorial development has been analyzed by many scholars within the research of cities and regions (for example, Bagwell, 2008; Seidel 2009; Comunian et al., 2011; Lazzeretti, 2013; Yu et al., 2014; De Beukelaer, 2014; Correa-Quezada et al., 2018).

The term "creative industries" first mentioned in the "Creative Industries Mapping Document" (DCMS/CITF, 1998) by the Creative Industries Task Force (CITF) commissioned by the Department for Culture, Media and Sport (DCMS) of the United Kingdom. According to the aforementioned study, creative industries are "based on individual creativity, ability, and talent" and have "the potential for wealth and job creation based on intellectual property" (DCMS/CITF, 1998). Initially, the list of creative industries included 13 types of economic activities:

- advertising;

- architecture;

- arts and antics;

- crafts;

- design;

- clothes modeling;

- cinematography;

- interactive entertainment software, including videogames;

- music;

- performing arts;

- press;

- $\quad$ software and information systems;

- television and radio.

This list of creative industries covered a large and varied area of economic activity. Nevertheless, it did not consider, for example, activities related to the preservation of cultural heritage. Between 1998 and 2006, CITF and DCMS of the United Kingdom examined a wide range of creative industries and changed their original list by shortening and regrouping it.

The term "creative economy" first mentioned in 2001 by media consultant J. Howkins in his book "The Creative Economy: How People Make Money from Ideas". J. Howkins defined the creative economy as follows: "... it is based on the transformation of the results of creativity into economically valuable goods and services" (Howkins, 2001). He proposed to subdivide creative industries into four groups depending on the subject of intellectual property: patent, trademark, industrial design, and copyright. This approach generally does not contradict the definition of creative industries proposed by CITF and DCMS of the United Kingdom. But J. Howkins' approach is considered more open, since he does not name creative industries a priori.

J. Howkins model of the creative economy contributed to the reorientation of "cultural" statistics and its indicators. In Montreal, at the International Symposium on Culture Statistics (2002) it was proposed to start using 


\section{ENTREPRENEURSHIP AND SUSTAINABILITY ISSUES}

ISSN 2345-0282 (online) http://jssidoi.org/jesi/ 2021 Volume 9 Number 2 (December)

http://doi.org/10.9770/jesi.2021.9.2(32)

the concept of creative economy (which has not previously been used in scientific literature) or, at least, to support the idea of the existence of creative industries (UNESCO Institute for Statistics, 2002).

More recently, the concept of "talent economy" has also appeared in the media space (less often in scientific literature) (Martin, 2014; Fulton, 2019). Since 1960 the U.S. economy has moved from largely financing the exploitation of natural resources to make the most of talent. The rewards to executives and financiers have skyrocketed as a result (Martin, 2014).

The general evolution of understanding of the creative economy is reflected in Figure 1.

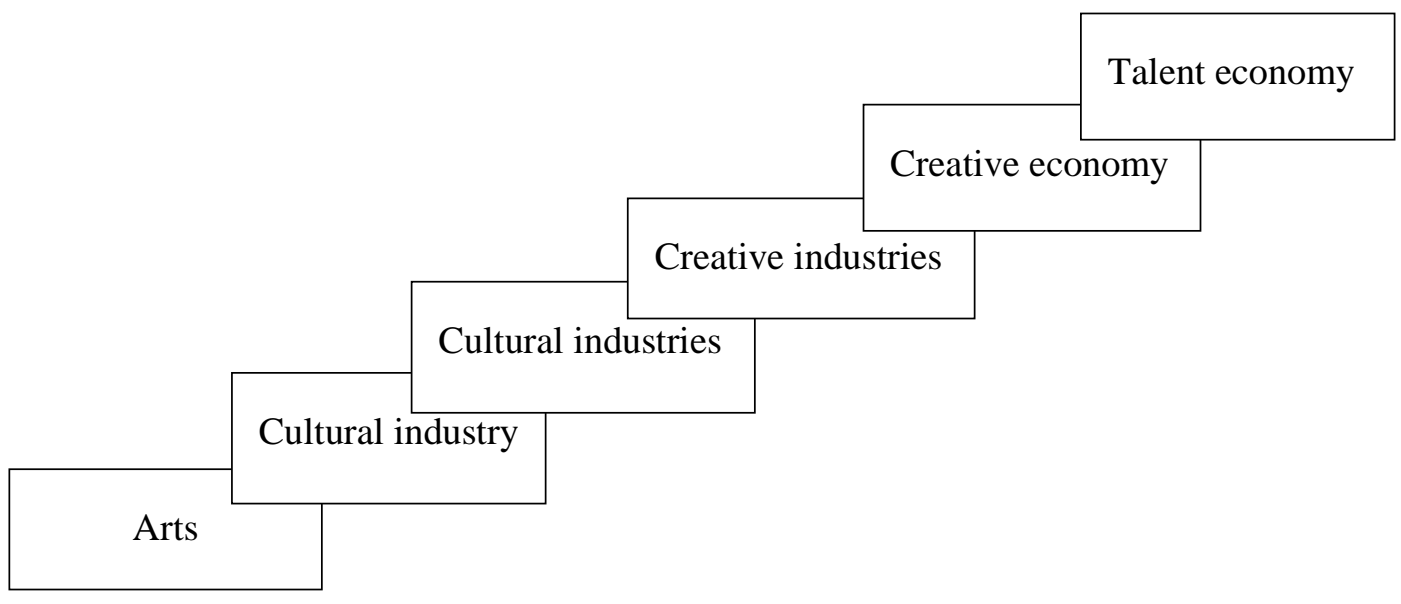

Figure 1. The general evolution of the understanding of talent economy

Source: combined by the authors based on Policy Research Group, 2013; Martin, 2014

Political and scientific interest in creativity, talent, and their impact on economic and territory development increased following the 2002 publication of R. Florida book "The Rise of the Creative Class, and How It's Transforming Work, Leisure, Community, and Everyday Life" (Florida, 2002b). R. Florida's creative class theory emerged in economic science as a part of a people-centered approach. According to this theory, the creativity, capabilities, and skills of people, together with technology and a tolerant cultural environment, are 3T: talent, technology, tolerance. Nowadays, all these elements increasingly determine the economic performance and growth of a territory (Florida \& Gates, 2001; Florida, 2002a, 2002b, 2003, 2005, 2006; Parilla, 2019).

If the territory has all these $3 \mathrm{Ts}$, it is able to attract talents with the capacity to innovate and boost economic growth. Attracting talents is followed by capital and the creation of innovative companies. In turn, attracting a talented workforce requires a diverse and tolerant society, leisure opportunities in both sport and culture, highlevel schools and higher education institutions, and a governance system that promotes and supports an attractive infrastructure for talented people. According to the creative class theory developed by R. Florida, those areas that are able to grow, retain, and attract talents have a competitive advantage (Florida, 2002a, 2003).

The International Labor Organization has announced that the combination of technological innovation, automation, and the creative industries is leading to exponential changes, mainly related to 'labor saving' tactics to increase productivity and competitiveness (ILO, 2016). In its turn, the UN publication "Creative Economy Outlook" notes that the digital transformation will continue to change working conditions in the coming years, but it will take place unevenly in different territories (United Nations, 2018). For instance, the Oxford Economics report "Global Talent 2021: How the New Geography of Talent Will Transform Human Resource Strategies" states that "in developing countries, talent is predominantly "home grown", and in the next decade, those regions 


\section{ENTREPRENEURSHIP AND SUSTAINABILITY ISSUES}

ISSN 2345-0282 (online) http://jssidoi.org/jesi/ 2021 Volume 9 Number 2 (December) http://doi.org/10.9770/jesi.2021.9.2(32)

of the world from which we do not expect it at all will create an oversupply of talent. In other regions, such as the United States and most European countries, there will be massive retraining of the workforce to meet the demand for higher-level skills in an increasingly digitalized and globalized world" (Oxford Economics, 2021).

The economic differentiation of countries around the world stems not only from differences between territories but also from differences between people. Thus, the economic differentiation of countries is actually the result of the distribution of human talent across territories (Gibbons et al., 2010). The two main components of geographical inequality have a spatial effect, i.e. the impact of an agglomeration on firms' efficiency, and the human effect, i.e. the impact of individuals on territorial development. Many studies have shown that the human effect dominates (Gibbons et al., 2010; Gibbons \& Vignoles, 2011; Kline \& Moretti, 2014; Carvalho et al., 2018; Akar et al., 2021). The biggest problem facing Europe's lagging territories is the lack of a skilled and competent workforce needed to attract investment and create a favorable environment for business development in the regions. For this reason, policies to tackle territorial inequalities in the $21^{\text {st }}$ century must be people-centered and not place-specific (European Trade Union Institute, 2011). Thus, the authors believe that the human-centered approach in Development Economics, as well as the creative class theory of R. Florida, offer a theoretical basis for proving the role of talent in the economic development of countries in the modern world.

\section{Research objective and methodology}

In world research practice, talent in relation to a territory is usually measured by perceiving the competitiveness of territory in terms of talent, rather than by applying it to individual sectors of the economy. The Global Talent Competitiveness Index (GTCI) is based on the provision that countries compete with each other in the global space by growing, attracting, and retaining talent that contributes to the country's competitiveness, innovation, and growth (INSEAD, 2018).

Table 1. Structure of the Global Talent Competitiveness Index (GTCI)

\begin{tabular}{|c|c|c|c|c|c|}
\hline \multicolumn{6}{|c|}{ Global Talent Competitiveness Index (GTCI) } \\
\hline \multicolumn{4}{|c|}{ Input } & \multicolumn{2}{|c|}{ Output } \\
\hline Enable & Attract & Grow & Retain & VT skills & GK skills \\
\hline $\begin{array}{l}\text { Regulatory } \\
\text { Landscape }\end{array}$ & $\begin{array}{c}\text { External } \\
\text { Openness }\end{array}$ & Formal Education & Sustainability & Mid-Level Skills & High-Level Skills \\
\hline Market Landscape & Internal Openness & Lifelong Learning & Lifestyle & Employability & Talent Impact \\
\hline $\begin{array}{c}\text { Business and } \\
\text { Labour Landscape }\end{array}$ & - & $\begin{array}{l}\text { Access to Growth } \\
\text { Opportunities }\end{array}$ & - & - & - \\
\hline
\end{tabular}

Note: VT skills - Vocational and technical skills; GK skills - Global knowledge skills

Source: INSEAD, 2017

In the Global Competitiveness Report (GCR) of the World Economic Forum, there are also indicators measuring, on a scale of 1 to 7, talent competitiveness of countries with two separate components (World Economic Forum, 2016, 2017):

- country capacity to attract talent;

- country capacity to retain talent.

In turn, the "Creative Economy Outlook" measures the competitiveness of territories in terms of talent, based on the volume of export of creative goods and services produced in the territory in millions of USD (United Nations, 2018):

- creative goods - art crafts, audiovisual products, design, digital products, new media, performing arts, publishing, visual arts; 
ENTREPRENEURSHIP AND SUSTAINABILITY ISSUES

ISSN 2345-0282 (online) http://jssidoi.org/jesi/ 2021 Volume 9 Number 2 (December)

http://doi.org/10.9770/jesi.2021.9.2(32)

- creative services - advertising, marketing research, and public opinion surveys; architectural, engineering services, research and development services, individual, cultural, and recreational services, audiovisual and related services.

R. Florida's creative class, J. Howkins's creative economy, and the UK government's creative industries emerged as a result of a number of topical discourses important to the modern economy. At the end of the $20^{\text {th }}$ century, the ideas of the knowledge economy came to the fore, so R. Florida and J. Howkins merged creative workers under the names 'creative class' and 'creative economy' linking them to the concepts of talent, creativity and innovation (Oakley, 2009).

Eurostat also points out that, in recent years, the term "creative economy" has become increasingly associated with all types of economic activity that are based on human creativity and talent, regardless of the economic sector in which it occurs. In this case, the creative economy emerges wherever human creativity, talent, nonstandard thinking is the main factor of production and profit-making (Eurostat, 2018a).

The authors consider this approach to be the most appropriate for the empirical measurement of the talent competitiveness of countries. The Latvian economist V. Nespors also believes that "in any profession, you can work creatively. Just as in any of the so-called creative professions, the proportion of workers with a completely uncreative approach to their professional activities is quite large. The same applies to industries and businesses. Being in the creative industry does not mean belonging to the creative economy" (Nespors, 2010: 90). The author's conceptual approach to understanding the creative economy, based on the analysis of scientific literature and analytic reports, is shown in Figure 2.

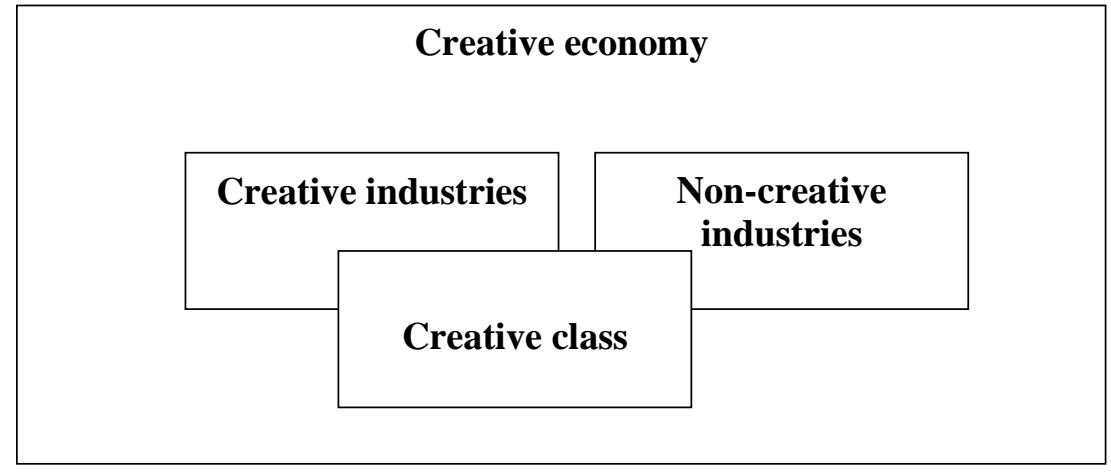

Figure 2. Mapping the creative class, the creative industries, and the creative economy

Note: it is no coincidence that in the figure a largest part of the creative class belongs to the creative industries - here the authors agree with the empirical interpretation of the creative class presented by R. Florida (Florida, 2002a: 87):

"A distinctive feature of the creative class is that its representatives are doing the work, the main function of which is creating meaningful new forms. In my view, the creative class splits into two components.

The super-creative core of the new class includes scientists and engineers, university professors, poets and writers, artists and actors, designers and architects, as well as the intellectual elite of modern society: publicists, editors, prominent cultural figures, experts from analytical centers, observers and other people whose views shape public opinion. In addition to this central group, the creative class includes "creative specialists" across a range of knowledge-based industries such as the high-tech sector, finance, law and healthcare, and business administration".

Source: elaborated by the authors, based on DCMS/CITF, 1998; Eurostat, 2018a; Howkins, 2001; Florida, 2002b, 2005, 2006; Policy Research Group, 2013; INSEAD, 2017

In turn, Eurostat methodology for the creative economy (according to Eurostat terminology - cultural economy) covers ten key economic sectors (Eurostat, 2018a): museums, archives, libraries, books and press, fine arts, 
theatres, audio- and video multimedia, architecture, advertising, arts crafts. First of all, indicators such as the number of active enterprises, the size of enterprises, sales volume, employment in creative industries, and the share of these sectors in GDP are analyzed.

Table 2. Employment in creative industries, ${ }^{*}$ GTCI,

indicators of economic performance and growth of the EU countries, $n=28$ countries, 2017

\begin{tabular}{|c|c|c|c|c|c|c|c|}
\hline \multirow{2}{*}{$\begin{array}{c}\mathbf{E U} \\
\text { countries }\end{array}$} & \multicolumn{2}{|c|}{$\begin{array}{c}\text { Employment in creative } \\
\text { industries }\end{array}$} & \multicolumn{2}{|c|}{$\begin{array}{c}\text { Export rate in creative } \\
\text { industries }\end{array}$} & \multirow{2}{*}{$\begin{array}{l}\text { GDP per } \\
\text { capita, } \\
\text { thousands } \\
\text { of USD }\end{array}$} & \multirow{2}{*}{$\begin{array}{c}\text { Average } \\
\text { annual } \\
\text { GDP } \\
\text { growth } \\
\text { during } \\
\text { 2007-2017, } \\
\%\end{array}$} & \multirow{2}{*}{$\begin{array}{c}\text { GTCI, score } \\
\text { from } 1 \text { to } \\
100\end{array}$} \\
\hline & $\begin{array}{c}\% \text { from } \\
\text { total } \\
\text { employment }\end{array}$ & $\begin{array}{l}\text { thousands } \\
\text { of people }\end{array}$ & $\begin{array}{c}\text { millions of } \\
\text { USD }\end{array}$ & $\begin{array}{l}\text { per one } \\
\text { employee, } \\
\text { USD }\end{array}$ & & & \\
\hline Austria & 4.2 & 180 & 534.7 & 2971 & 47.3 & +0.9 & 68.63 \\
\hline Belgium & 4.3 & 205 & 7952.2 & 38791 & 43.6 & +0.9 & 69.56 \\
\hline Bulgaria & 2.7 & 84 & 448.4 & 5338 & 8.1 & +1.9 & 45.72 \\
\hline Croatia & 3.3 & 54 & 284.4 & 5267 & 13.1 & -0.2 & 45.42 \\
\hline Cyprus & 3.5 & 14 & 39.1 & 2793 & 25.0 & +0.2 & 50.29 \\
\hline Czechia & 3.7 & 198 & 6647.9 & 33575 & 20.2 & +1.5 & 60.02 \\
\hline Denmark & 4.2 & 119 & 3712.7 & 31199 & 56.4 & +0.6 & 73.79 \\
\hline Estonia & 5.6 & 37 & 528.7 & 14289 & 19.8 & +0.5 & 61.93 \\
\hline France & 3.6 & 966 & 21439.3 & 22194 & 39.9 & +0.7 & 62.61 \\
\hline Finland & 4.9 & 126 & 747.1 & 5929 & 46.0 & 0.0 & 73.95 \\
\hline Germany & 4.0 & 1661 & 29158.2 & 17555 & 44.5 & +1.2 & 67.77 \\
\hline Greece & 3.3 & 125 & 808.7 & 6470 & 18.6 & -2.9 & 48.21 \\
\hline Hungary & 3.4 & 150 & 1380.9 & 9206 & 15.5 & +1.0 & 44.25 \\
\hline Ireland & 3.4 & 77 & 1329.7 & 17269 & 70.6 & +4.1 & 71.38 \\
\hline Italy & 3.6 & 831 & 30512.1 & 36717 & 32.0 & -0.6 & 50.55 \\
\hline Latvia & 3.5 & 32 & 407.7 & 12741 & 15.5 & +0.1 & 52.27 \\
\hline Lithuania & 4.0 & 56 & 1329.1 & 23734 & 16.7 & +1.3 & 53.31 \\
\hline Luxembourg & 5.3 & 15 & 174.3 & 11620 & 105.8 & +2.0 & 71.64 \\
\hline Malta & 5.2 & 12 & 185.4 & 15450 & 27.3 & +4.2 & 58.77 \\
\hline Netherlands & 4.6 & 408 & 10055.4 & 24646 & 48.3 & +0.9 & 72.56 \\
\hline Poland & 3.6 & 586 & 6477.4 & 11054 & 13.8 & +3.3 & 50.06 \\
\hline Portugal & 3.2 & 158 & 1673.5 & 10592 & 21.2 & -0.1 & 55.75 \\
\hline Romania & 1.6 & 141 & 1367.4 & 9698 & 10.8 & $+2,4$ & 41.13 \\
\hline Slovakia & 2.8 & 72 & 1728.4 & 24006 & 17.7 & +2.4 & 50.02 \\
\hline Slovenia & 4.7 & 47 & 772.3 & 16432 & 23.7 & +0.6 & 55.77 \\
\hline Spain & 3.5 & 678 & 6505.2 & 9595 & 28.4 & +0.3 & 54.91 \\
\hline Sweden & 4.6 & 235 & 3508.5 & 14930 & 53.2 & +1.6 & 74.32 \\
\hline $\begin{array}{l}\text { United } \\
\text { Kingdom }\end{array}$ & 4.5 & 1471 & 24187.3 & 16443 & 39.7 & +1.1 & 73.11 \\
\hline
\end{tabular}

* According to Eurostat: cultural employment

Source: Eurostat, 2018b; United Nations, 2018; INSEAD, 2018; World Economic Forum, 2018; calculations of the authors

The authors believe that when analyzing the talent competitiveness of a territory, a creative people-oriented approach is more efficient than a creative industries-oriented approach, even though it is less economic. The reasoning for this position seems to be simple enough for the authors, since in the creative industries not all employees perform creative activities. For instance, in museums, archives, libraries, and theaters people also work in "non-creative" positions such as accountants, cashiers, cleaners, security guards, etc. Probably because some EU countries have a relatively high share of "non-creative" workers in the creative industries, these countries have a low export rate per employee in the creative industries (Table 2). On the other hand, such industries as science, education, medicine, catering are not on the list of creative industries, although many talented scientists, teachers, doctors, culinary and confectioners work in them, which increase not only the competitiveness of their 


\section{ENTREPRENEURSHIP AND SUSTAINABILITY ISSUES}

ISSN 2345-0282 (online) http://jssidoi.org/jesi/ 2021 Volume 9 Number 2 (December)

http://doi.org/10.9770/jesi.2021.9.2(32)

industries but also the competitiveness of territories where they live. The authors argue that talented people are necessary and employable in any sector of the economy, not just in the limited list of creative industries. Thus, it is significant that the main topic of the report "The Global Talent Competitiveness Index 2019: Entrepreneurial Talent and Global Competitiveness" became entrepreneurial talent that can be used in any economic sector (INSEAD, 2019).

In order to empirically prove that a creative people-oriented approach to exploring the talent competitiveness of a territory is more efficient than creative industries-oriented approach, the authors carried out a correlation analysis in the sample of EU countries.

Table 3. Interconnection between employment in creative industries, GTCI and some economic indicators in the EU countries, Pearson correlation coefficient, $\mathrm{n}=28$ countries, 2017

\begin{tabular}{|c|c|c|}
\hline Correlated variables & $\begin{array}{c}\text { Employment in } \\
\text { creative industries, } \\
\% \text { from total employment }\end{array}$ & GTCI, score from 1 to 100 \\
\hline $\begin{array}{l}\text { GDP per capita, } \\
\text { thousands of USD }\end{array}$ & $\begin{array}{c}0.510 \\
p=0.003\end{array}$ & $\begin{array}{c}0.795 \\
p=0.001\end{array}$ \\
\hline $\begin{array}{l}\text { Average annual GDP growth during 2007- } \\
2017, \%\end{array}$ & $\begin{array}{c}0.026 \\
p=0.011\end{array}$ & $\begin{array}{c}0.137 \\
\mathrm{p}=0.010\end{array}$ \\
\hline $\begin{array}{l}\text { Export rate in creative industries, per one } \\
\text { employee, USD }\end{array}$ & $\begin{array}{c}0.141 \\
\mathrm{p}=0.006\end{array}$ & $\begin{array}{c}0.290 \\
p=0.000\end{array}$ \\
\hline $\begin{array}{l}\text { Interconnection between employment in } \\
\text { creative industries ( } \% \text { from total } \\
\text { employment) and GTCI }\end{array}$ & \multicolumn{2}{|c|}{$\begin{array}{c}0.684 \\
p=0.014\end{array}$} \\
\hline
\end{tabular}

Source: calculated by the authors using data of Table 2

The results of the correlation analysis in the sample of EU countries presented in Table 3 show that the GTCI is closer than the relative employment in creative industries, correlates with both GDP per capita and GDP growth rate, as well as with exports of creative industries per employee. With all three indicators selected for the correlation analysis, the Pearson correlation coefficient for GTCI is significantly higher than for the relative employment in creative industries (Table 3). It should be emphasized that these "indicators-competitors" - the relative employment in creative industries and GTCI - are moderately and statistically significantly proportionally correlate between themselves (Table 3). Therefore, based on the results of correlation analysis and following the previous logical analysis the authors will use GTCI for further empirical research as an indicator more closely linked to the economic performance and growth of territory than relative employment in creative industries. The additional argument for this choice is the fact that the export rate in creative industries per employee, for instance, in Belgium is 7.4 times higher than in Croatia (Table 2). This means that the indicator of relative employment in creative industries does not, in itself (without taking into consideration the above-mentioned export rate in creative industries per employee) indicate the efficiency of creative industries in a particular country.

As for measuring the economic development of countries, as already indicated in the Introduction to this article, the authors use for this purpose one static indicator - GDP per capita for the current year (an indicator of economic performance), as well as a dynamic indicator - the average annual GDP growth during the previous 10 years (an indicator of economic growth) (World Economic Forum, 2017, 2018, 2019).

For an empirical study of the role of talent in the countries' economic development in the modern world, the authors used the method of linear regression analysis with stepwise inclusion of factor variables. Regression analysis was carried out on three samples of countries of the world - for 2016 (INSEAD, 2017; World Economic Forum, 2016, 2017), for 2017 (INSEAD, 2018; World Economic Forum, 2017, 2018) and for 2018 (INSEAD, 2019; World Economic Forum, 2018, 2019) separately for the indicator "GDP per capita (by the purchasing 
power parity, PPP)" and the indicator "average annual GDP growth during the previous 10 years". As factor variables, in addition to talent indicators (GTCI and two above-mentioned "talent" indicators from the Global Competitiveness Report (excluding Global Competitiveness Report 2018)), the authors also included in the analysis 12 "background" factor variables - pillars of the Global Competitiveness Index (GCI), which are rated for the world's countries on a scale from 1 (minimum) to 7 (maximum) (World Economic Forum, 2017, 2018, 2019). These "background" factors (GCI pillars) have undergone some changes during the three years studied (Table 4).

\begin{tabular}{|c|c|c|}
\hline \multirow{2}{*}{$\begin{array}{l}\text { Serial number } \\
\text { within the GCI }\end{array}$} & \multicolumn{2}{|c|}{ Pillars of the Global Competitiveness Index (GCI) } \\
\hline & 2016 & 2018 \\
\hline 1 & \multicolumn{2}{|c|}{ Institutions } \\
\hline 2 & \multicolumn{2}{|c|}{ Infrastructure } \\
\hline 3 & Macroeconomic environment & ICT adoption \\
\hline 4 & Health and primary education & Macroeconomic stability \\
\hline 5 & Higher education and training & Health \\
\hline 6 & Goods market efficiency & Skills \\
\hline 7 & Labor market efficiency & Product market \\
\hline 8 & Financial market development & Labor market \\
\hline 9 & Technological readiness & Financial system \\
\hline 10 & \multicolumn{2}{|c|}{ Market size } \\
\hline 11 & Business sophistication & Business dynamism \\
\hline 12 & Innovation & Innovation capability \\
\hline
\end{tabular}

Source: elaborated by the authors based on World Economic Forum, 2016, 2017, 2018

In addition to the results obtained over three years, the authors also analyzed the available data for 2019. Although, of all the data available for the period 2016-2018, in 2019 only data on GDP per capita (by the purchasing power parity) and GTCI were published for 132 countries (INSEAD, 2020).

\section{Results and discussion}

As a result of the regression analysis, the following regression equations were obtained for the period 2016-2018:

where:

$$
y=-46.763+3.976 x_{14}+1.208 x_{13}
$$

y - GDP per capita (PPP), thousands of USD, 2016

$\mathrm{x}_{14}$ - country capacity to attract talent, score from 1 to 7,2016

$\mathrm{x}_{13}-\mathrm{GTCI}$, score from 1 to 100,2016

Excluded variables:

$\mathrm{x}_{1}$ - institutions, score from 1 to 7, 2016

$\mathrm{x}_{2}$ - infrastructure, score from 1 to 7,2016

$\mathrm{x}_{3}$ - macroeconomic environment, score from 1 to 7, 2016

$\mathrm{x}_{4}$ - health and primary education, score from 1 to 7, 2016

$\mathrm{x} 5$ - higher education and training, score from 1 to 7, 2016

$\mathrm{x}_{6}$ - goods market efficiency, score from 1 to 7, 2016

$\mathrm{x}_{7}$ - labour market efficiency, score from 1 to 7, 2016

$\mathrm{x}_{8}$ - financial market development, score from 1 to 7, 2016

$\mathrm{x} 9$ - technological readiness, score from 1 to 7, 2016

$\mathrm{x}_{10}$ - market size, score from 1 to 7, 2016

$\mathrm{x} 11$ - business sophistication, score from 1 to 7, 2016

$\mathrm{x} 12$ - innovation, score from 1 to 7, 2016

$\mathrm{x}_{15}$ - country capacity to retain talent, score from 1 to 7,2016

Source: calculated by the authors using the SPSS software based on the data of INSEAD, 2017; World Economic Forum, 2016,2017 
ENTREPRENEURSHIP AND SUSTAINABILITY ISSUES

ISSN 2345-0282 (online) http://jssidoi.org/jesi/

2021 Volume 9 Number 2 (December)

http://doi.org/10.9770/jesi.2021.9.2(32)

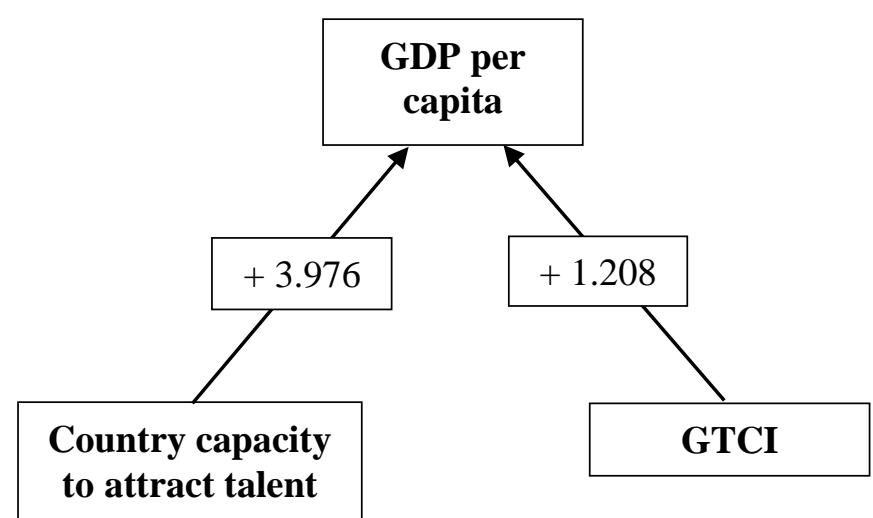

Figure 3. The role of talent in economic performance of the world's countries, statistically significant factor variables and the $\beta$ coefficients of the regression equation, $\mathrm{n}=114$ countries, 2016

Source: elaborated by the authors based on regression Equation 1

Since the Global Competitiveness Reports, which contain empirical data for 2016 (World Economic Forum, 2016, 2017), does not contain data on the economic growth of countries over the past 10 years, in 2016 it was possible to assess the impact of talent only on the static element of economic development of the modern world's countries - their economic performance, measured by the GDP per capita (Equation 1). Statistically significant factors stimulating the economic performance of the countries in 2016 turned out to be 2 out of 15 potentially possible: the country's capacity to attract talents and GTCI (Figure 3). Thus, in the presence of indicators related to talent in the set of potential factors of the economic performance of the countries, all other factors did not have a statistically significant effect on GDP per capita in 2016.

where:

$$
y=-13.779-6.969 x_{5}+5.910 x_{12}-4.704 x_{7}+1.289 x_{13},
$$

y - GDP per capita (PPP), thousands of USD, 2017

$\mathrm{X}_{5}$ - higher education and training, score from 1 to 7, 2017

$\mathrm{x}_{12}$ - innovation, score from 1 to 7, 2017

$\mathrm{x}_{7}$ - labor market efficiency, score from 1 to 7, 2017

$\mathrm{x}_{13}-\mathrm{GTCI}$, score from 1 to 100,2017

Excluded variables:

$\mathrm{x}_{1}-$ institutions, score from 1 to 7,2017

$\mathrm{x}_{2}$ - infrastructure, score from 1 to 7,2017

X3 - macroeconomic environment, score from 1 to 7, 2017

$\mathrm{x}_{4}$ - health and primary education, score from 1 to 7, 2017

$\mathrm{x}_{6}$ - goods market efficiency, score from 1 to 7, 2017

$\mathrm{x}_{8}$ - financial market development, score from 1 to 7, 2017

$\mathrm{x} 9$ - technological readiness, score from 1 to 7,2017

$\mathrm{x} 10$ - market size, score from 1 to 7, 2017

$\mathrm{x} 11$ - business sophistication, score from 1 to 7, 2017

$\mathrm{X} 14$ - country capacity to attract talent, score from 1 to 7,2017

$\mathrm{x}_{15}$ country capacity to retain talent, score from 1 to 7,2017

Source: calculated by the authors using the SPSS software based on the data of INSEAD, 2018; World Economic Forum, 2017,2018 


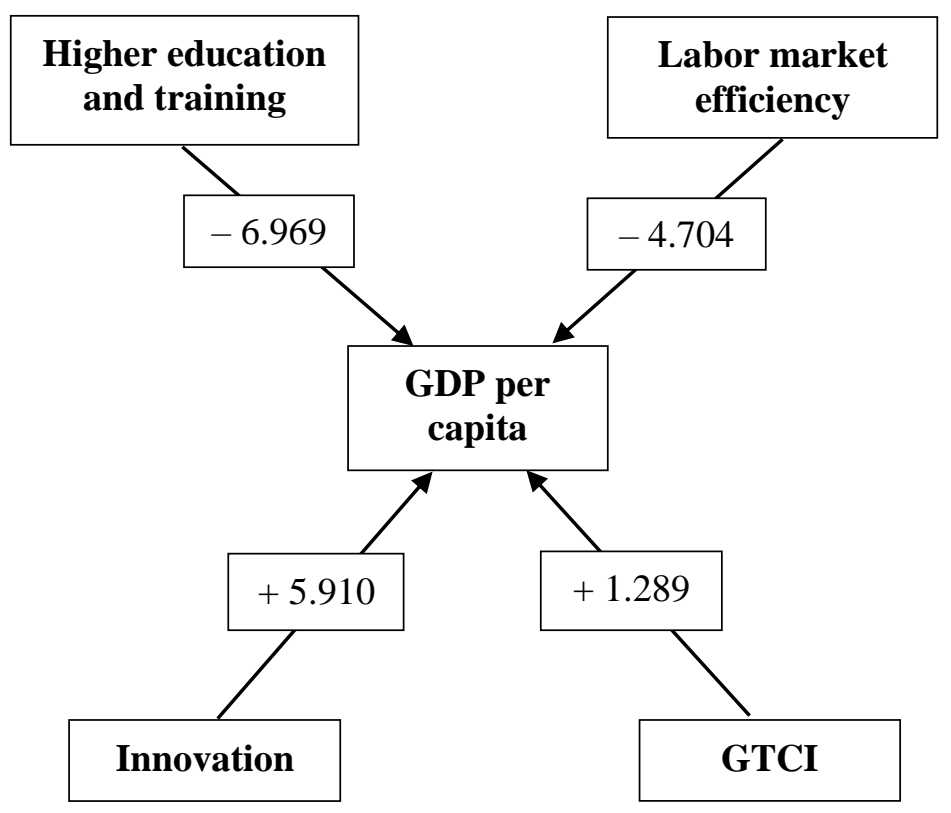

Figure 4. The role of talent in economic performance of the world's countries, statistically significant factor variables and the $\beta$-coefficients of the regression equation, $\mathrm{n}=117$ countries, 2017

Source: elaborated by the authors based on regression Equation 2

The results of the regression analysis of the role of talent in the economic performance of the world's countries in the next -2017 - year show that there are several factors that statistically significantly affect the economic performance of countries. For example, factors such as innovation and GTCI increase the economic performance of the world's countries, while factors such as higher education and training, as well as labor market efficiency, even reduce the economic performance of countries (Equation 2 and Figure 4). Among 15 factors, 12 of which are pillars of the Global Competitiveness Index, only two factors statistically significantly increase the economic performance of the world's countries - these are innovation and, again, GTCI (which, in a sense, can be considered synonymous). It is interesting that the factor of higher education and vocational training does not contribute to an increase in the economic performance of the world's countries, but on the contrary, reduces it. The Latvian researchers A. Stankevics, S. Ignatjeva, and V. Mensikovs concluded approximately the same: the high indicators of the world's countries in higher education and vocational training contribute to an increase in GDP per capita only if these countries are highly developed in technological readiness. Otherwise, the factor of higher education and vocational training does not contribute to the economic performance of countries but rather decreases it (for example, in the form of the so-called "brain drain") (Stankevics et al., 2014).

$$
\mathrm{y}=0.983+1.508 \mathrm{x}_{14}+0.683 \mathrm{x}_{3}-0.144 \mathrm{x}_{13},
$$

where:

$\mathrm{y}$ - average annual GDP growth during 2007-2017, \%

$\mathrm{x}_{14}-$ country capacity to attract talent, score from 1 to 7,2017

$\mathrm{x}_{3}$ - macroeconomic environment, score from 1 to 7, 2017

$\mathrm{x}_{13}-\mathrm{GTCI}$, score from 1 to 100,2017

Excluded variables:

$\mathrm{x}_{1}$ - institutions, score from 1 to 7,2017

$\mathrm{x}_{2}$ - infrastructure, score from 1 to 7, 2017 
$\mathrm{x}_{4}$ - health and primary education, score from 1 to 7, 2017

$\mathrm{x}_{5}$ - higher education and training, score from 1 to 7, 2017

X6-goods market efficiency, score from 1 to 7, 2017

$\mathrm{x} 7$ - labor market efficiency, score from 1 to 7, 2017

$\mathrm{x}_{8}$ - financial market development, score from 1 to 7, 2017

$\mathrm{x}_{9}$ - technological readiness, score from 1 to 7, 2017

$\mathrm{x}_{10}$ - market size, score from 1 to 7, 2017

$\mathrm{x}_{11}$ - business sophistication, score from 1 to 7, 2017

$\mathrm{x}_{12}$ - innovation, score from 1 to 7, 2017

$\mathrm{X}_{15}-$ country capacity to retain talent, score from 1 to 7,2017

Source: calculated by the authors using the SPSS software based on the data of INSEAD, 2018; World Economic Forum, 2017,2018

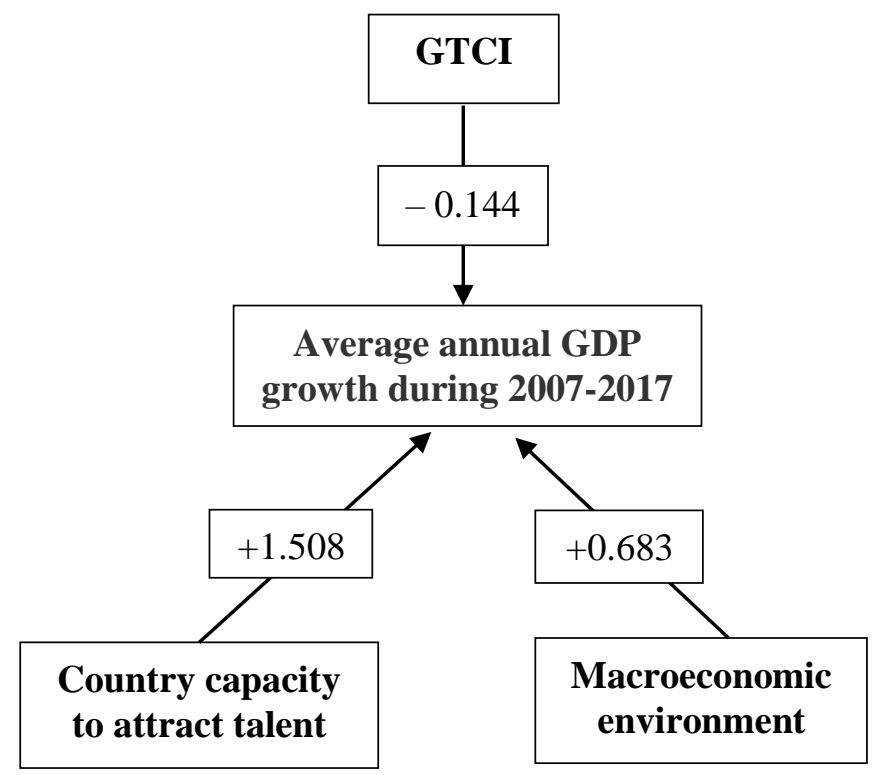

Figure 5. The role of talent in economic growth of the world's countries, statistically significant factor variables and the $\beta$-coefficients of the regression equation, $\mathrm{n}=117$ countries, 2017

Source: elaborated by the authors based on regression Equation 3

In turn, two out of 15 factors have the greatest stimulating effect on the economic growth of the world's countries in 2017: the macroeconomic environment and the country's capacity to attract talent (Equation 3 and Figure 5). Interestingly, the ability of a particular country to attract talent, in contrast to the GTCI as a whole, ${ }^{1}$ is the most powerful of the 15 factors included in the regression analysis and becomes practically the main stimulus for the economic growth of the countries. However, the stable and sustainable economic performance of countries in the modern world requires their fuller competitiveness in talent, which includes the ability of countries to enable, attract, grow and retain talents (i.e. GTCI). It is interesting that the GTCI in 2017 negatively affects the economic growth of the world's countries - most likely because the implementation of all the above components of the GTCI requires large investments and really slows down short-term economic growth.

\footnotetext{
${ }^{1}$ Country's capacity to attract talent is a separate indicator in the World Economic Forum's Global Competitiveness Reports (World Economic Forum, 2017, 2018), but it is also an integral part of the GTCI (INSEAD, 2017, 2018, 2019, 2020).
} 


$$
y=8.740+1.548 x_{13}-0.677 x_{11}-0.578 x_{6}+0.464 x_{3},
$$

where:

y - GDP per capita (PPP), thousands of USD, 2018

$\mathrm{x}_{13}$ - GTCI, score from 1 to 100,2018

$\mathrm{x}_{11}$ - business dynamism, score from 1 to 100, 2018

$\mathrm{x} 6$ - skills, score from 1 to 100,2018

$\mathrm{x}_{3}-\mathrm{ICT}$ adoption, score from 1 to 100, 2018

Excluded variables:

$\mathrm{x}_{1}$ - institutions, score from 1 to 100,2018

$\mathrm{x}_{2}$ - infrastructure, score from 1 to 100,2018

$\mathrm{x}_{4}$ - macroeconomic stability, score from 1 to 100,2018

$\mathrm{x}_{5}$ - health, score from 1 to 100,2018

$\mathrm{x}_{7}$ - product market, score from 1 to 100,2018

$\mathrm{x}_{8}$ - labour market, score from 1 to 100,2018

$\mathrm{x} 9$ - financial system, score from 1 to 100,2018

$\mathrm{x}_{10}$ - market size, score from 1 to 100,2018

x12- innovation capability, score from 1 to 100, 2018

Source: calculated by the authors using the SPSS software based on the data of INSEAD, 2019; World Economic Forum, 2018,2019

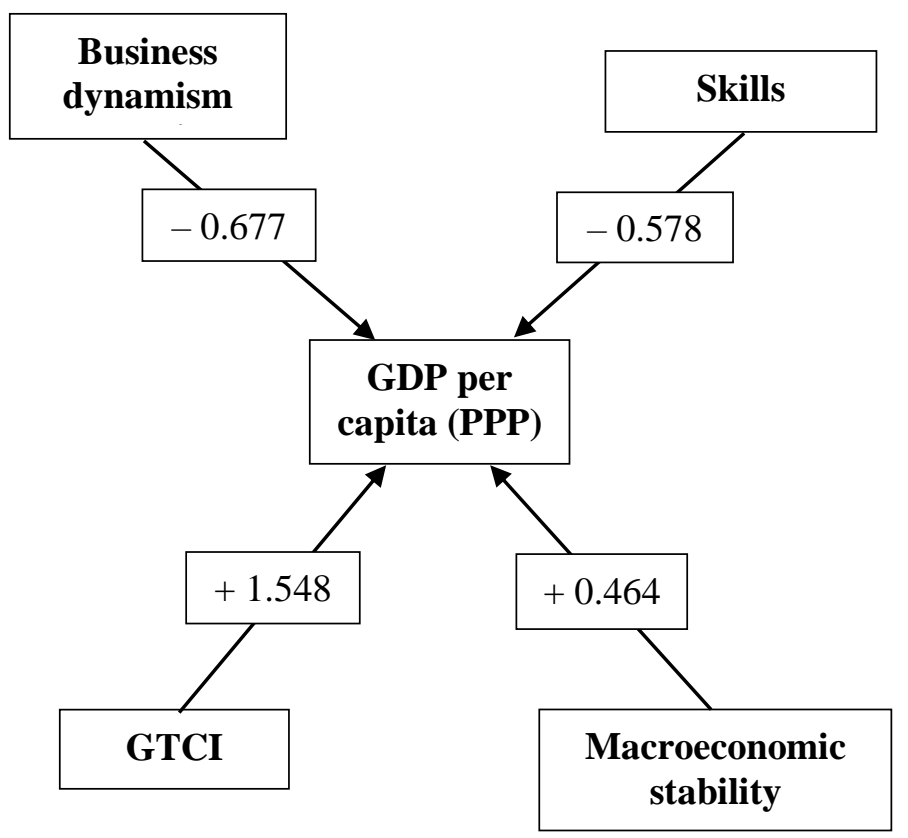

Figure 6. The role of talent in economic performance of the world's countries, statistically significant factor variables and the $\beta$-coefficients of the regression equation,

$$
\mathrm{n}=122 \text { countries, } 2018
$$

Source: elaborated by the authors based on regression Equation 4

In 2018, the economic performance of the world's countries was positively and statistically significantly influenced by such factors as the GTCI (which is consistent with the results for 2016 and 2017) and macroeconomic stability (Equation 4 and Figure 6). In turn, factors such as business dynamism and skills are 


\section{ENTREPRENEURSHIP AND SUSTAINABILITY ISSUES}

ISSN 2345-0282 (online) http://jssidoi.org/jesi/ 2021 Volume 9 Number 2 (December) http://doi.org/10.9770/jesi.2021.9.2(32)

factors that statistically significantly reduce the economic performance of countries in the modern world. With regard to the skills' factor, ${ }^{2}$ this result practically confirms the result obtained in 2017. As for the business dynamism (in 2016 and 2017 this factor was called "business sophistication" and included more subjective estimates), the authors find it difficult to explain the negative impact of this factor on the economic performance of the world's countries - especially since this is observed only in 2018 (perhaps, this is the beginning of some new trend or pattern that requires further study).

where:

$$
y=3.413-0.097 x_{6}+0.095 x_{8},
$$

$\mathrm{y}$ - average annual GDP growth during 2008-2018, \%

$\mathrm{x}_{6}-$ skills, score from 1 to 100,2018

$\mathrm{x}_{8}$ - labour market, score from 1 to 100, 2018

Excluded variables:

$\mathrm{x}_{1}$ - institutions, score from 1 to 100,2018

$\mathrm{x}_{2}$ - infrastructure, score from 1 to 100,2018

$\mathrm{x}_{3}-\mathrm{ICT}$ adoption, score from 1 to 100, 2018

$\mathrm{x}_{4}$ - macroeconomic stability, score from 1 to 100, 2018

$\mathrm{x}_{5}$ - health, score from 1 to 100,2018

$\mathrm{x}_{7}$ - product market, score from 1 to 100,2018

$\mathrm{X} 9$ - financial system, score from 1 to 100,2018

$\mathrm{x}_{10}$ - market size, score from 1 to 100,2018

x 11 - business dynamism, score from 1 to 100, 2018

$\mathrm{X} 12$ - innovation capability, score from 1 to 100, 2018

x13-GTCI, score from 1 to 100, 2018

Source: calculated by the authors using the SPSS software based on the data of INSEAD, 2019; World Economic Forum, 2018,2019

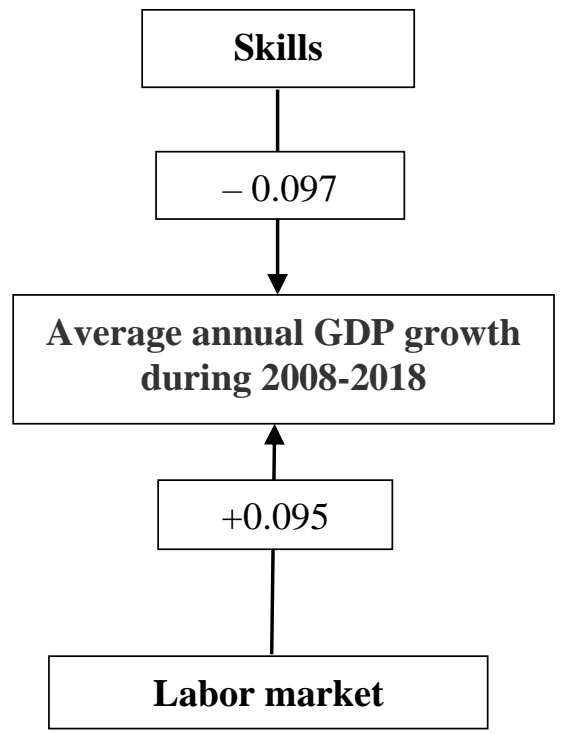

Figure 7. The role of talent in economic growth of the world's countries, statistically significant factor variables and the $\beta$-coefficients of the regression equation, $\mathrm{n}=122$ countries, 2018

Source: elaborated by the authors based on regression Equation 5

\footnotetext{
2 The "skills" indicator (World Economic Forum, 2018, 2019) replaced the previous "higher education and training" indicator (World Economic Forum, 2017), stressing professional skills of the workforce (for example, critical thinking and digital skills) instead of the emphasis on the education system (for example, secondary and tertiary education enrollment rate, Internet access in schools, etc.).
} 
The results of the regression analysis for economic growth in 2018 show that the factor of workforce skills began to negatively affect not only the static indicator of the economic development of the world's countries - economic performance of countries (Figure 6), but also the dynamic indicator - their economic growth (Figure 7). In turn, the factor that statistically significantly accelerates the economic growth of the world's countries in 2018 is only the labor market (while since 2018 such indicators as the country's capacity to attract and retain talent are no longer measured separately).

In the following Table 5, for a complex perception of the results of the regression analysis, the authors summarized statistically significant factors - both stimulating and inhibiting the economic performance and economic growth of countries in the modern world.

Table 5. Summary table of factors that statistically significantly inhibit and stimulate the economic development of countries in the modern world, 2016-2018

\begin{tabular}{|c|c|c|c|c|c|c|}
\hline \multirow{2}{*}{$\begin{array}{c}\text { Components of } \\
\text { countries' } \\
\text { economic } \\
\text { development }\end{array}$} & \multicolumn{2}{|c|}{$\begin{array}{c}2016 \\
n=114 \text { countries }\end{array}$} & \multicolumn{2}{|c|}{$\begin{array}{c}2017 \\
\mathrm{n}=117 \text { countries }\end{array}$} & \multicolumn{2}{|c|}{$\begin{array}{c}2018 \\
n=122 \text { countries }\end{array}$} \\
\hline & $\begin{array}{c}\text { Inhibiting } \\
\text { factors }\end{array}$ & $\begin{array}{c}\text { Stimulating } \\
\text { factors }\end{array}$ & $\begin{array}{c}\text { Inhibiting } \\
\text { factors }\end{array}$ & $\begin{array}{c}\text { Stimulating } \\
\text { factors }\end{array}$ & $\begin{array}{c}\text { Inhibiting } \\
\text { factors }\end{array}$ & $\begin{array}{c}\text { Stimulating } \\
\text { factors }\end{array}$ \\
\hline $\begin{array}{c}\text { Economic } \\
\text { performance }\end{array}$ & $\begin{array}{l}\text { No such } \\
\text { factors }\end{array}$ & $\begin{array}{c}\text { Country } \\
\text { capacity to } \\
\text { attract talents, } \\
\text { GTCI }\end{array}$ & $\begin{array}{c}\text { Higher } \\
\text { education and } \\
\text { training, labor } \\
\text { market } \\
\text { efficiency }\end{array}$ & $\begin{array}{l}\text { Innovation, } \\
\text { GTCI }\end{array}$ & $\begin{array}{c}\text { Skills, } \\
\text { business } \\
\text { dynamism }\end{array}$ & $\begin{array}{c}\text { GTCI, } \\
\text { macroeconomic } \\
\text { stability }\end{array}$ \\
\hline Economic growth & $\begin{array}{r}\text { Economic } \\
\mathrm{me}\end{array}$ & $\begin{array}{l}\text { uwth was not } \\
\text { ured }\end{array}$ & GTCI & $\begin{array}{c}\text { Country } \\
\text { capacity to } \\
\text { attract talents, } \\
\text { macroeconomic } \\
\text { environment }\end{array}$ & Skills & Labor market \\
\hline
\end{tabular}

Source: elaborated by the authors based on regression Equations 1-5

The summarized data of the regression analysis for the period 2016-2018, shown in Table 5, allow the authors to empirically prove the significant stimulating role of talent in the economic development of countries in the modern world. It is only necessary to stress that talent, measured for the world's countries by the Global Talent Competitiveness Index, mainly stimulates the static component of the economic development of countries - their achieved economic performance, but not dynamic economic growth. But it is the achieved economic performance, according to the authors, that is the key component of the phenomenon of economic development of a territory.

For 2019, the Global Competitiveness Index (with all its pillars - factors for regression analysis in the framework of this study) was not measured (World Economic Forum, 2020). Thus, the authors used data of the report on the Global Talent Competitiveness Index, GTCI (INSEAD, 2020) in order to measure the role of talent, at least only in the economic performance of the world's countries (in 2020, the World Economic Forum did not provide data on economic growth for the previous 10 years).

$$
y=-30.692+1.244 x_{1}
$$

where:

$\mathrm{y}$ - GDP per capita (PPP), thousands of USD, 2019

$\mathrm{x}_{1}-\mathrm{GTCI}$, score from 1 to 100,2019

Source: calculated by the authors using the SPSS software based on the data of INSEAD, 2020 


\section{ENTREPRENEURSHIP AND SUSTAINABILITY ISSUES}

ISSN 2345-0282 (online) http://jssidoi.org/jesi/ 2021 Volume 9 Number 2 (December) http://doi.org/10.9770/jesi.2021.9.2(32)

The data of the regression equation 6 for 2019 confirms the results of the author's calculations, made according to the data for 2016-2018 and indicates that talent statistically significantly contributes to the economic performance of the countries in the modern world.

Based on stable empirical results obtained by regression analysis of data for more than 100 countries of the world over four years, the authors believe that the Global Talent Competitiveness Index (GTCI) could now practically replace the Global Competitiveness Index (GCI). In order to support their proposal with empirical data, the authors calculated the correlative relationship between GTCI and GCI for the period 2016-2018.

Table 6. The correlative relationship between the Global Talent Competitiveness Index (GCI) and the Global Competitiveness Index (GCI), 2016-2018

\begin{tabular}{|l|c|c|c|}
\hline \multicolumn{1}{|c|}{ Correlation parameters } & 2016 & 2017 & 2018 \\
\cline { 2 - 4 } & $\mathrm{n}=114$ countries & $\mathrm{n}=117$ countries & $\mathrm{n}=122$ countries \\
\hline $\begin{array}{l}\text { Pearson correlation } \\
\text { coefficient }\end{array}$ & 0.903 & 0.945 & 0.939 \\
\hline Statistical significance & 0.000 & & 0.000 \\
\hline Probability & $99 \%$ & $99 \%$ & $99 \%$ \\
\hline
\end{tabular}

Source: compiled and calculated by the authors using the SPSS program based on the data of INSEAD, 2017, 2018, 2019; World Economic Forum, 2017, 2018, 2019

The data of Table 6 empirically substantiate the authors' proposal on the feasibility of replacing the Global Competitiveness Index (GCI) with the Global Talent Competitiveness Index (GTCI), since both of these indices consistently show a very close correlation relationship. GTCI already has been successfully introduced into global research practice and has been calculated for at least 4 years (INSEAD, 2017, 2018, 2019, 2020).

\section{Conclusions}

The concept of talent has become frequently used in the scientific economic literature and global economic research as the main driving force of the talent economy. In order to empirically prove the role of talent in the economic development of countries in the modern world, the authors chose a methodological approach based on talent competitiveness. The competitiveness-based approach has been quite successfully applied in global research practice when studying and comparing countries- for example, in the framework of the annual report on the Global Talent Competitiveness Index (INSEAD, 2017, 2018, 2019, 2020).

The results of the author's empirical research have shown that competitiveness in terms of talent is indeed a stable and practically the main determinant of a key component of the economic development of the modern world's countries - their achieved economic performance. At the same time, the talent competitiveness of countries is not the engine of their short-term economic growth (another component of economic development). Research results show that it is enough to attract talent from the outside for economic growth. Thus, in order to be economically sustainable in the long-term, the modern world's countries have to be able to nurture talents and create conditions for their efficient activity within the country - all these elements are included in the Global Talent Competitiveness Index. Based on the empirical results obtained, the authors propose for the global research practice to replace the Global Competitiveness Index (GCI) with the Global Talent Competitiveness Index (GTCI), thus introducing the concept of talent also into the conceptual understanding of the competitiveness of countries in the modern world. 


\section{ENTREPRENEURSHIP AND SUSTAINABILITY ISSUES}

ISSN 2345-0282 (online) http://jssidoi.org/jesi/

2021 Volume 9 Number 2 (December)

http://doi.org/10.9770/jesi.2021.9.2(32)

\section{References}

Akar, G., Saritas, T., \& Kizilkaya, O. (2021). The Impact of Human Development on Economic Growth: An Application on Transition Economies. Business and Economics Research Journal, 12(3), 307-318. https://doi.org/10.20409/berj.2021.323

Andersson, A. (1985). Creativity and regional development. Papers in Regional Science, 56(1), 5-20. https://doi.org/10.1007/BF01887900

Bagwell, S. (2008). Creative clusters and city growth. Creative Industries Journal, 1(1), 31-46. https://doi.org/10.1386/cij.1.1.31 1

Boronenko, V., Mensikovs, V., \& Lavrinenko, O. (2014). The impact of EU accession on the economic performance of the countries' internal (NUTS 3) regions. Proceedings of Rijeka School of Economics, 32(2), 313-341.

Burzynski, M., Deuster, Ch., \& Docquier, F. (2018). The geography of talent: development implications and long-run prospects.

Development Policies, Working Paper No. 221. Retrieved September 10, 2021, from https://ferdi.fr/dl/df-

oC5YjcfTDFgS8ruKbaWjELSw/ferdi-p221-the-geography-of-talent-development-implications-and-long-run.pdf

Carvalho, L., Rego, C., Lucas, M.R., Sanchez-Hernandez, M.I., \& Noronha, A. (2018). Entrepreneurship and Structural Change in Dynamic Territories: Contributions from Developed and Developing Countries. Springer.

Cizo, E., Lavrinenko, O., \& Ignatjeva, S. (2020). Analysis of the relationship between financial development and economic growth in the EU countries. Insights into Regional Development, 2(3), 645-660. https://doi.org/10.9770/IRD.2020.2.3(3)

Comunian, R., Faggian, A., \& Jewell, S. (2011). Winning and losing in the creative industries: an analysis of creative graduates' career opportunities across creative disciplines. Cultural Trends, 20(3-4), 91-308. https://doi.org/10.1080/09548963.2011.589710

Correa-Quezada, R., Alvarez-Garcia, J., Rio-Rama, M., \& Maldonado-Erazo, C. (2018). Role of creative industries as a regional growth factor. Sustainability, 10(5), 1649. https://doi.org/10.3390/su10051649

Cowling, M. (2009). The Geographical Distribution of UK Talent: causes and consequences. Working Paper WP24. Institute for Employment Studies. Retrieved September 10, 2021, from https://www.employment-studies.co.uk/resource/geographical-distribution-uktalent-causes-and-consequences

Cubas, G., Ravikumar, B., \& Ventura, G. (2016). Talent, labor quality, and economic development, Review of Economic Dynamics, 21, 160-181. https://doi.org/10.1016/j.red.2015.06.004

DCMS/CITF (1998). Creative Industries Mapping Document. Retrieved September 10, 2021, from https://www.gov.uk/government/publications/creative-industries-mapping-documents-1998

De Beukelaer, C. (2014). Creative industries in "developing” countries: Questioning country classifications in the UNCTAD creative economy reports, Cultural Trends, 23, 232-251. https://doi.org/10.1080/09548963.2014.912043

Ding, Y.Y., Yao, F.G., Lv, H.X., \& Hu, Y. (2020). Interaction between marine economic development and talent cultivation: the result of canonical correlation analysis. Journal of Coastal Research, 103, 79-84. https://doi.org/10.2112/SI103-017.1

European Trade Union Institute (2011). Regional Inequalities in Europe. Retrieved September 10, 2021, from https://www.etui.org/content/download/5425/53612/file/Chap+7.pdf

Eurostat (2018a). Guide to Eurostat Culture Statistics 2018. Retrieved September 10, 2021, from

https://ec.europa.eu/eurostat/web/products-manuals-and-guidelines/-/KS-GQ-18-011

Eurostat (2018b). Culture statistics - cultural employment. Retrieved September 10, 2021, from https://ec.europa.eu/eurostat/statisticsexplained/index.php/Culture_statistics_-_cultural_employment\#Cultural_employment_E2.80.94_overall_developments

Florida, R. (2002a). The economic geography of talent. Annals of the American Association of Geographers, 92(4), 743-755. https://doi.org/10.1111/1467-8306.00314

Florida, R. (2002b). The Rise of the Creative Class, and How It's Transforming Work, Leisure, Community and Everyday Life. New York: Basic Books.

Florida, R. (2003). Cities and the Creative Class. City \& Community, 2(1), 3-19. https://doi.org/10.1111/1540-6040.00034

Florida, R. (2005). Cities and the Creative Class. New York: Routledge.

Florida, R. (2006). The Flight of the Creative Class: The New Global Competition for Talent. New York: Harper Business.

Florida, R., \& Gates, G. (2001). Technology and Tolerance: The Importance of Diversity to High-Tech Growth. Washington: DC Brookings Instituion, Center for Urban and Metropolitan Policy. 


\section{ENTREPRENEURSHIP AND SUSTAINABILITY ISSUES}

ISSN 2345-0282 (online) http://jssidoi.org/jesi/ 2021 Volume 9 Number 2 (December)

http://doi.org/10.9770/jesi.2021.9.2(32)

Gibbons, S., \& Vignoles, A. (2011). Geography, choice and participation in higher education in England. Regional Science and Urban Economics, 42(1-2), 98-113. https://doi.org/10.1016/j.regsciurbeco.2011.07.004

Gibbons, S., Overman, H., \& Pelkonen, P. (2010). Wage disparities in Britain: people or place? Retrieved September 10, 2021, from: http://eprints.lse.ac.uk/30845/1/sercdp0060.pdf (accessed 10 September 2021

Gu, H., Meng, X., Shen, T., \& Wen, L. (2020). China's Highly Educated Talents in 2015: Patterns, Determinants and Spatial Spillover Effects. Applied Spatial Analysis and Policy, 13(2), 631-648. https://doi.org/10.1007/s12061-019-09322-6

Gu, H.Y., Rowe, F., Liu, Y., \& Shen, T.Y. (2021). Geography of talent in China during 2000-2015: an Eigenvector Spatial Filtering Negative Binomial approach. Chinese Geographical Science, 31(2), 297-312. https://doi.org/10.1007/s11769-021-1191-y

Howkins, J. (2001). The Creative Economy: How People Make Money from Ideas. London: Penguin.

ILO (International Labour Office) (2016). Technological changes and work in the future: making technology work for all. Retrieved September 10, 2021, from https://www.ilo.org/wcmsp5/groups/public/---dgreports/---dcomm/documents/publication/wcms_534201.pdf

INSEAD (The Business School for the World) (2017). The Global Talent Competitiveness Index 2017: Talent and Technology. Retrieved September 10, 2021, from https://www.insead.edu/sites/default/files/assets/dept/globalindices/docs/GTCI-2017-report.pdf

INSEAD (The Business School for the World) (2018). The Global Talent Competitiveness Index 2018: Diversity for Competitiveness. Retrieved September 10, 2021, from https://www.insead.edu/sites/default/files/assets/dept/globalindices/docs/GTCI-2018-report.pdf

INSEAD (The Business School for the World) (2019). The Global Talent Competitiveness Index 2019: Entrepreneurial Talent and Global Competitiveness. Retrieved September 10, 2021, from https://www.insead.edu/sites/default/files/assets/dept/globalindices/docs/GTCI2019-Report.pdf

INSEAD (The Business School for the World) (2020). The Global Talent Competitiveness Index 2020: Global Talent in the Age of Artificial Intelligence. Retrieved September 10, 2021, from https://www.insead.edu/sites/default/files/assets/dept/globalindices/docs/GTCI2020-report.pdf

Jiang, H., Zhang, W., \& Duan, J. (2020). Location Choice of Overseas High-Level Young Returned Talents in China. Sustainability, 12, 9210. https://doi.org/10.3390/su12219210

Kerimoglu, E., \& Karahasan, B. (2012). Geography of talent for understanding regional disparities in Spain. Journal of Urban and Regional Analysis, 4(2), 103-128. https://doi.org/10.37043/JURA.2012.4.2.1

Kline, P., \& Moretti, E. (2014). People, places, and public policy: some simple welfare economics of local economic development policies, Annual Review of Economics, 6, 629-662. https://doi.org/10.1146/annurev-economics-080213-041024

Kondratiuk-Nierodzinska, M. (2016). New knowledge generation capabilities and economic performance of Polish regions. Equilibrium. Quarterly Journal of Economics and Economic Policy, 11(3), 451-471. https://doi.org/10.12775/EQUIL.2016.021

Krysovatyy A., Fedosov V., Tymchenko O., \& Silchenko M. (2020). Taxation, economic growth and welfare in a low-income country. Economic Annals XXI, 181(1-2), 44-56. https://doi.org/10.21003/ea.V181-04

Lazzeretti, L. (2013). Creative Industries and Innovation in Europe: Concepts, Measures and Comparative Case Studies. London: Routledge.

Martin, R. (2014). The rise (and likely fall) of the talent economy. Retrieved September 10, 2021, from https://hbr.org/2014/10/the-riseand-likely-fall-of-the-talent-economy

MEPRD (Ministry of Environmental Protection and Regional Development of the Republic of Latvia) (2020). Sustainable Development Strategy of Latvia until 2030. Retrieved September 10, 2021, from http://www.varam.gov.lv/lat/pol/ppd/?doc=13857 (in Latvian)

Nespors, V. (2010). Radosa ekonomika un augstakas izglitibas problemas Latvija. Economics and Business. Economy: Theory and Practice, 20, 90-93. (in Latvian)

NZIER (New Zealand Institute of Economic Research) (2014). Regional economies: shape, performance and drivers. NZIER Public Discussion Papers, 2014/03. Retrieved September 10, 2021, from https://nzier.org.nz/publication/regional-economies-shape-performanceand-drivers-nzier-working-paper20143

Oakley, K. (2009). The disappearing arts: creativity and innovation after the creative industries. International Journal of Cultural Policy, 15(4), 403-441. https://doi.org/10.1080/10286630902856721

Oxford Economics (2021). Global Talent 2021: How the New Geography of Talent Will Transform Human Resource Strategies. Retrieved September 10, 2021, from https://www.oxfordeconomics.com/Media/Default/Thought\%20Leadership/global-talent-2021.pdf 


\section{ENTREPRENEURSHIP AND SUSTAINABILITY ISSUES}

ISSN 2345-0282 (online) http://jssidoi.org/jesi/ 2021 Volume 9 Number 2 (December)

http://doi.org/10.9770/jesi.2021.9.2(32)

Parilla, J. (2019). Talent is precious. That's why economic development should focus on developing it. Economic Prosperity, December 11. Retrieved September 10, 2021, from https://better-cities.org/economic-prosperity/talent-is-precious-thats-why-economic-developmentshould-focus-on-developing-it/

Policy Research Group (Ed.) (2013). The Creative Economy: Key Concepts and Literature Review Highlights. Retrieved September 10, 2021, from https://cch.novascotia.ca/sites/default/files/inline/documents/creative-economy-synthesis_201305.pdf

Porter, M. (2003). The economic performance of regions. Regional Studies, 37(6-7), 549-578. https://doi.org/10.1080/0034340032000108688

Rauch, J. (1993). Productivity gains from geographic concentrations of human capital: evidence from cities. Journal of Urban Economics, 34(3), 380-400. https://doi.org/10.1006/juec.1993.1042

Raudeliuniene, J., Tvaronaviciene, M., \& Blazyte, M. (2020). Knowledge Management Practice in General Education Schools as a Tool for Sustainable Development. Sustainability, 12(10), 4034. https://doi.org/10.3390/su12104034

Seidel, S. (2009). Toward a Theory of Managing Creativity-Intensive Processes: A Creative Industries Study. Liechtenstein: SpringerVerlag.

Shevyakova, A., Munsh, E., Arystan, M., \& Petrenko, Y. (2021). Competence development for Industry 4.0: Qualification requirements and solutions. Insights into Regional Development, 3(1), 124-135. https://doi.org/10.9770/IRD.2021.3.1(7)

Stankevics, A., Ignatjeva, S., \& Mensikovs, V. (2014). Higher education's contribution to economic performance and innovativeness in Latvia: exploratory research. Economic Annals, 202(59), 7-41.

Tian, L., \& Liu, N.C. (2018). Local and global public good contributions of higher education in China. Working paper no. 37. Retrieved September 10, 2021, from https://www.researchcghe.org/perch/resources/publications/wp37.pdf

Tsvyk, V.A., \& Tsvyk, I.V. (2020). Social assessment of technology and humanitarization of engineering in the information society. RUDN Journal of Sociology, 20(3), 471-486. https://doi.org/10.22363/2313-2272-2020-20-3-471-486 (in Russian)

UNESCO Institute for Statistics (2002). Proceedings of the International Symposium on Culture Statistics. Retrieved September 10, 2021, from http://uis.unesco.org/sites/default/files/documents/proceedings-of the-international-symposium-on-cultural-statistics-2002-en-fre.pdf

United Nations (2018). Creative Economy Outlook. Retrieved September 10, 2021, from https://unctad.org/en/PublicationsLibrary/ditcted2018d3_en.pdf

World Economic Forum (2016). The Global Competitiveness Report 2016-2017. Retrieved September 10, 2021, from https://www3.weforum.org/docs/GCR2016-2017/05FullReport/TheGlobalCompetitivenessReport2016-2017_FINAL.pdf

World Economic Forum (2017). The Global Competitiveness Report 2017-2018. Retrieved September 10, 2021 from https://www.weforum.org/reports/the-global-competitiveness-report-2017-2018

World Economic Forum (2018). The Global Competitiveness Report 2018. Retrieved September 10, 2021, from https://www.weforum.org/reports/the-global-competitveness-report-2018

World Economic Forum (2019). The Global Competitiveness Report 2019. Retrieved September 10, 2021, from https://www3.weforum.org/docs/WEF_TheGlobalCompetitivenessReport2019.pdf

World Economic Forum (2020). The Global Competitiveness Report 2020. Retrieved September 10, 2021, from https://www.weforum.org/reports/the-global-competitiveness-report-2020

Yang, Z.S, \& Pan, Y.H. (2020). Human capital, housing prices, and regional economic development: Will "vying for talent" through policy succeed? Cities, 98, Article Number: 102577 https://doi.org/10.1016/j.cities.2019.102577

Yu, W., Hong, J., Zhu, Y., \& Marinova, D. (2014). Creative industry clusters, regional innovation and economic growth in China. Regional Science Policy \& Practice, 6(4), 329-347. https://doi.org/10.1111/rsp3.12051

Zhang, R., \& Zhao, C.P. 2018. research on the correlation model of vocational talents, population structure and economic development. Wireless Personal Communications, 102(2), 985-996. https://doi.org/10.1007/s11277-017-5127-x

Zobena, A. (Ed.) (2007). Latvija. Parskats par tautas attistibu 2006/2007. Cilvekkapitals: mans zelts ir mana tauta? (Latvia. Human Development Report 2006/2007. Human capital: my gold is my nation?) Riga: LU Socialo un politisko petijumu instituts. 


\section{ENTREPRENEURSHIP AND SUSTAINABILITY ISSUES}

ISSN 2345-0282 (online) http://jssidoi.org/jesi/

2021 Volume 9 Number 2 (December)

http://doi.org/10.9770/jesi.2021.9.2(32)

Liene LEIKUMA-RIMICANE (Mg.oec.) is the Ph.D. student at Daugavpils University (Latvia). She has the status of the science communication expert of Daugavpils University, where she combines scientific background, research and writing experience, and projectmanagement skills. Research interests: talent economy, social entrepreneurship, regional economics, sustainable development, universal basic income.

ORCID ID: https://orcid.org/0000-0002-4677-4795

Vera KOMAROVA (Dr.oec.) is the leading researcher at the Social Investigations Centre of the Institute of Humanities and Social Sciences of Daugavpils University (Latvia). She has the status of the expert of Latvian Council of Science in the field of economics and entrepreneurship and the external expert of the COST Association. Research interests: regional economics, sustainable development, creative economy, social research methodology, quantitative research methods, social stratification.

ORCID ID: https://orcid.org/0000-0002-9829-622X

Jelena LONSKA (Dr.oec., corresponding author) is the researcher at the Business and Society Process Research Center of Rezekne Academy of Technologies (Latvia), as well as the associated professor at the Faculty of Economics and Management. She has the status of the expert of the Latvian Council of Science in the field of economics and entrepreneurship. Research interests: regional economics, creative economy, sustainable development, measuring the state of development of countries.

ORCID ID: $\underline{\text { https://orcid.org/0000-0002-8140-4810 }}$

Natalya Selivanova-FYODOROVA (Dr.oec.) is the lecturer at the RISEBA University of Applied Sciences (Latvia). Her research interests: macroeconomics, differentiation of territories, regional economics, creative economy, quantitative research methods.

ORCID ID: https://orcid.org/0000-0001-8561-4869

Inta OSTROVSKA (Dr.paed.) is the Docent at the Department of Economics of Faculty of Social Sciences of Daugavpils University (Latvia). She is also PhD student of the programme "Regional Economics" at the Latvia University of Life Sciences and Technologies. Her research interests: creativity, critical thinking, social and economic development, regional economics, sustainable development, smart growth.

ORCID ID: https://orcid.org/0000-0003-1484-5752

Make your research more visible, join the Twitter account of ENTREPRENEURSHIP AND SUSTAINABILITY ISSUES: @ Entrepr69728810

Copyright (C) 2021 by author(s) and VsI Entrepreneurship and Sustainability Center

This work is licensed under the Creative Commons Attribution International License (CC BY).

http://creativecommons.org/licenses/by/4.0/

(c) (i) Open Access 